\title{
RESTRUCTURING THE NATIONAL PROFESSIONAL QUALIFICATION FOR EDUCATIONAL LEADERS (NPQEL) IN MALAYSIA: A SUMMARY REPORT
}

\author{
Gurcharan Singh Bishen Singh \\ Open University Malaysia \\ Corresponding Author Email: gurcharan_singh@oum.edu.my
}

\begin{abstract}
The National Professional Qualification for Educational Leaders (NPQEL) is an in-service training programme for leadership and management initiated by the Ministry of Education (MOE) Malaysia through its educational management and leadership institute, IAB (Institut Aminuddin Baki). Beginning July 2014, the NPQEL becomes a mandatory requirement for aspiring headteachers who want to be appointed into headship. This article presents the background of this programme, stemming from the earlier National Professional Qualification for Headship (NPQH) programme which was modelled after the NPQH in England. The programme, which was introduced in 1999, then went through some structural changes and in 2011, the new mode NPQEL was introduced which adopted the blending learning approach. Research on the NPQH and the NPQEL is also presented and these informed the formulation of the new mode NPQEL in 2011, and the eventual NPQEL 2018 version or NPQEL 2.0. The structures of the NPQEL new mode (2011) and NPQEL version 2018 are also discussed.
\end{abstract}

Keywords: NPQEL, Headship preparatory training, School leadership, Headship prerequisite programme

\section{INTRODUCTION}

Even though the concept of leadership is purportedly derived mainly from the business world, it found its way into the educational world. Bush and Glover (2003) in reviewing the broad literature on School Leadership for the National College for School Leadership define school leadership as follows:

Leadership is a process of influence leading to the achievement of desired purposes. Successful leaders develop a vision for their schools based on their personal and professional values. They articulate this vision at every opportunity and influence their staff and other stakeholders to share the vision. The philosophy, structures and activities of the school are geared towards the achievement of this shared vision/l (p. 8).

Sammons et al. (1995, p. 8) have identified eleven factors for effective schools and have asserted the importance of the leadership factor. Sammons (1999, p. 195) claims that 'almost every single study of school effectiveness has shown both primary and secondary leadership to be a key factor'. Reynolds and Teddlie (2000, p. 141) declare that they did not know of a study that has not shown leadership as an important factor within effective schools and asserted that this leadership is 'nearly always provided by the headteacher' (p. 141). Hallinger and Heck (1999) who reviewed previous research 
conclude that leadership of school heads is linked only indirectly to school effectiveness. However, they confirmed that the principals provide the most powerful influence in clarifying and articulating the purposes of the school.

In the UK the Department for Education and Employment (DfES) has made the following statement:

The quality of the headteacher is a crucial factor in the success of the school...Good heads can transform a school; poor heads can block progress and achievement. It is essential that we have measures in place to strengthen the skills of all new and serving heads (DfEE, 1998, p. 2946).

In concluding their study on the influence of school leadership on pupil learning, Leithwood et al. (2006) made the following claim:

There is not a single documented case of a school successfully turning around its pupil achievement trajectory in the absence of talented leadership (p. 5).

The importance of school leadership in determining the quality and effectiveness of schools was asserted by many researchers. Similar sentiments were expressed in Malaysia amongst the policymakers and scholars alike. Wan Zahid (1995), a Malaysian educational scholar and the then Director-General of Education, asserts that leadership and management are the most important phenomena to move the trained and knowledgeable workforce forward. According to a report of a meeting by Effective Principals Movement on 5 March 1998 effective school leaders should have excellent communication skills, good human relations, sensitivity to diverse cultures and customs, possess clear vision, ability to create a dynamic educational environment, ability to accept tasks as a professional responsibility, ability to make decisions through consensus, and, skills in information technology and management, and other personal skills (EPRD, 2006, p. 8-9).

The Ministry of Education Malaysia envisioned preparing an able group of school leaders who are capable of managing schools effectively. An effective headteacher is one who has good qualities in leadership, interpersonal communication, work targets and demonstrates good personality (EPRD, 2006).

The above-desired characteristics of school leaders in Malaysia have much in common with the ideas in western perspectives. The adaptation of ideas from the West is not without problems because of the varying contextual differences, such as differences in school governance and culture. This prompted scholars from the Asia Pacific region to call for the development of an indigenous knowledge base on leadership, one that is moulded with the culture and local context taken into account (Bajunid, 1996; Cheng, 1995; Hallinger and Kantamara, 2000; Shah, 2006). However, it can be assumed that the knowledge base on school leadership has been influenced greatly by western perspectives. This influence continues and it is further amplified by ICT and globalisation (Aziz, 2003). 
Notwithstanding the effect of the training on the school, Bush (2008) made a strong call that school leaders should be accorded proper development as he describes it as a 'moral obligation':

Requiring individuals to lead schools, which are often multimillion-dollar businesses, manage staff and care for children, without specific preparation, may be seen as foolish, even reckless, as well as being manifestly unfair for the new incumbent/l (p. 30).

It has also been claimed that formal training for school leadership has been relatively rare outside the USA (Willower \& Forsyth, 1999). Brundrett (2001) informs that school leadership preparation can be traced back to the nineteenth century, making the USA the first nation that formulated a theory of educational administration. In the same vein, Murphy (1997) reported that educational master degrees are mandatory in many American states and 35 states have adopted or adapted the Interstate School Leaders Licensure Consortium (ISLLC) standards.

In England, there were several disconnected initiatives in the training of school leadership and management during the 1980s and 1990s (Bush, 1998). However, the introduction of Headteachers Leadership and Management Programme (HEADLAMP) in 1995 to address the training needs of newly appointed heads, followed by the National Professional Qualification for Headship (NPQH) for aspiring heads in 1997, and the establishment of the National College for School Leadership (NCSL) in November 2000 signalled a much higher profile for school leadership and leadership preparation (Bush \& Jackson, 2002).

In Malaysia, headship training has been provided by Institut Aminuddin Baki (IAB - The National Institute of Educational Management and Leadership) since its inception in 1979. In-service courses in the form of basic course for practising heads - the one-month School Management and Leadership course and other short courses that are relevant to headship roles are provided. In 1999, the first cohort of aspiring heads was enrolled to take up the NPQH (National Professional Qualification for Headship) course.

\section{BACKGROUND}

The initiatives to improve schools and enhance the quality of headteachers is a desirable measure by many countries around the world. School leaders are an integral part of the aspirations for school effectiveness due to their roles and responsibilities (Adams, 2018; Daniëls, Hondeghem \& Dochy, 2019). Three qualification improvement initiatives for the school leaders are training for future principals, an induction course for the already appointed principals and a qualification improvement course for principals with school management experience (Zelvys, Dukynaite, Vaitekaitis \& Jakaitiene, 2019). A headteacher is not merely an administrator but should also be a leader capable of developing the human resources in the organisation (Adams, A. Samat \& A. Samah, 2018). The ever-growing demand on the role of the school head warrants appropriate training for heads to be equipped with the skills and knowledge in leading schools in the $21^{\text {st }}$ century. Given this ever-increasing responsibilities, the importance of developing school leaders has been established internationally (Lumby 2014; Walker 2015). Even 
though there is higher expectations from school leaders, it seems that most of them receive little structured preparation for the role (Pashiardis \& Johansson, 2016).

The National Professional Qualification for Educational Leaders (NPQEL) is an in-service training programme for leadership and management initiated by the Ministry of Education (MOE) Malaysia through its educational management and leadership institute, IAB (Institut Aminuddin Baki). This programme was initially known as the National Professional Qualification for Headship (NPQH).

The NPQH was a one-year fulltime headship preparatory programme from its inception in 1999 until 2007. Similar to its namesake in England, the NPQH in Malaysia was a programme for aspiring school heads. Around the world, much emphasis is being given to leadership development programmes as an element to enhance school effectiveness and improve educational systems. Hallinger and Snidvongs (2008) assert it as following:

The current focus on school leader preparation reflects the importance societies around the world are placing upon the goal of improving their educational systems. The investment of substantial new resources into leadership preparation and development activities is based upon the belief that school leaders make a difference in both the effectiveness and efficiency of schooling/l (p. 9 -emphasis in original).

Similar to its namesake in England, the NPQH in Malaysia was developed for aspiring school heads. The NPQH was introduced in 1999 due to three main factors. Firstly, knowledge in the educational field was developing ever so rapidly globally and the demand for quality headship education worldwide was also felt in Malaysia. Thus, it was apt to prepare aspiring school heads in Malaysia with the latest relevant knowledge and skills. The new knowledge and skills will enable them to use conception and craft skills continuously in their workplace (Guskey, 2000). Secondly, it was in tandem with the recommendations put forth by the Mahathir Report 1979 (Cabinet Committee, 1979) on the training of school administrators. The report proposed a setting up of local management and leadership training institute for the officers of the Ministry of Education. This was to reduce the dependence on overseas training due to the constraints of expenditure and the limited number of officers that could be sent at any one time (Cabinet Committee, 1979). The third factor was the influence of ideas and practices derived from professional development courses attended by the officials from the Ministry of Education in renowned institutions abroad. Thus, the licensure requirements for principalship in the United States (Council of Chief State School Officers, CCSSO, 1996) and the training framework of the English NPQH by Teacher Training Agency in 1998 (Lodge, 1998) were referred to when producing the framework for the NPQH in Malaysia (Aziz, 2003).

The need to improve school performances through the development of school leaders has been given priority by many countries (Lumby et al., 2008). Apart from the NPQH in the UK (Bush et al., 2010), the Principal Qualification Programme in Ontario, Canada and Certificate for Principalship in Hong Kong (Huber \& West, 2002) are among the mandatory programmes for aspiring school principals. This is apt as there is a great deal of evidence pointing towards the significant impact of school principal leadership on 
organisational capacity and student outcomes (Adams, Raman Kutty \& Mohd Zabidi, 2017; Hallinger, Adams, Harris \& Jones, 2018).

The NPQH programme from 1999 until 2007, and then NPQEL from 2007 until 2010 was a one-year fulltime programme divided into two phases of six months each. The first phase involved six months of fulltime residential input given to participants in the main campus of IAB in Genting Highlands, Pahang or its branch campus in the northern state of Kedah. This phase incorporated three weeks of practice in a school chosen by each participant. The second phase of six months involved the Attachment programme in a school. The participant would choose a school in the same district as his or her school. In the six months, the participants were required to do tasks and report them in three portfolios. They were assigned a supervisor each - a trainer from IAB - who will visit them two or three times during the attachment to advise them as well as monitor their progress. There were altogether 13 cohorts of participants in the NPQH/NPQEL one-year programme from 1999 until 2010.

In 2007 the programme was renamed National Professional Qualification for Educational Leaders (NPQEL) but maintained its one-year full-time structure. The programme was revamped in 2010 and its structure changed from a one-year full-time training to a fivemonth training using the blended learning approach. The total course duration of this new mode NPQEL is five months (20 weeks) comprising of six weeks face to face learning and 14 weeks of elearning. The first batch of new mode NPQEL participants joined the programme in July 2011 and completed the course in November 2011. Since then two batches of participants go through this programme every year.

Even though the NPQH in England was one of the references for the NPQH in Malaysia, the former was dropped by the coalition government in 2012, on the 'dubious grounds that schools should be able to choose whom to appoint' (Bush, 2016). In Malaysia, however, this programme gained more attention and a clear emphasis to focus on the need to prepare high-performing principals was made in the Malaysian Education Blueprint (MEB) which is a major reform of the education system spanning 12 years, from 2013 to 2025. The concern of Malaysia's low ranking in international reviews of learner performance, such as Trends in International Mathematics and Science Study (TIMSS) and Programme for International Student Assessment (PISA) led to the Ministry emphasizing on development of principals who can provide the instructional leadership believed to be necessary to improve student outcomes (Ministry of Education, 2012: E4). The assertion by Leithwood et al. (2006) that high performing principals could improve student outcomes was echoed in the MEB, that 'the quality of school leaders is the second biggest school-based factor in determining student outcomes, after teacher quality (Ministry of Education, 2012: E-27).

The need to prepare incoming school principals also stemmed from the fact that ' $55 \%$ of today's principals received no preparatory or induction training before or during their formative first three years of principalship', as reported in the MEB (Ministry of Education, 2012: E-17). It was, therefore, necessary to have enough preparation for aspiring school leaders leading to their appointment as school heads. 


\section{RESEARCH ON NPQH/NPQEL}

A few studies have been done on the effectiveness of the NPQH as well as NPQEL programme in Malaysia. The first study was done by Aziz (2003), aimed at examining the effectiveness of the NPQH training based on the participants' perceptions of the training they received in three areas - knowledge and skills, dispositions, and performance. The study involved 214 participants of the first three cohorts of the programme, of which 148 were graduates and 66 were still undergoing training. The study found that the graduates and trainees perceived they had improved significantly in the respective areas - knowledge/skills, dispositions and performance, due to the training they received. Although the graduates had benefited from the training, it was found that the graduates were frustrated as they could not get the headship posts. It was also found that the respondents were not satisfied with some trainers as some of them were unskillful in adult learning and possibly lacking in understanding of adult needs. This study was conducted on primary school graduates and only three of them had assumed headship.

The second study was conducted by the Educational Policy and Research Division (EPRD), Ministry of Education Malaysia. The study was done from 2003 and the findings presented in 2006 (EPRD, 2006). It aimed at researching the effectiveness of NPQH graduates at the management level in schools. The study involved $150 \mathrm{NPQH}$ graduates who have been appointed to management posts in school (Head, Senior Assistant, Subject leader). It also involved 115 graduates who had not been appointed to any management post and were assuming the role of ordinary teachers. This study also sought information from 600 administrators and teachers in schools where the graduates were posted. All the sample were given a questionnaire and 16 graduates were interviewed in the second phase - eight of whom were in management posts and another eight were ordinary teachers. The study found that NPQH graduates demonstrated high ability in applying knowledge and skills acquired from the training. The administrators and teachers in schools where the NPQH graduates were posted to also resoundingly approved of the effectiveness of these graduates in terms of personal quality and leadership abilities. The study also found some areas of concern, namely, the graduates viewed that there was no clear policy and planning on their placement after the training, and the input for certain areas in the training such as financial management and legal aspects should be enhanced.

The third study in Malaysia was done in IAB (the training provider) and reported by Hassan et al. (2006). It reported on the findings of the evaluation at the end of the 6month theoretical phase of the course by $202 \mathrm{NPQH}$ participants. The study employed the internal tools of IAB for evaluating end of course reactions of participants (Lecturer Evaluation Form BK-9 and Program Evaluation Form BK-10). The questionnaire contained in these forms used close-ended and open-ended items, administered as soon as the programme ends. This evaluation found that 76 per cent of the participants responded that the course objectives were fully achieved; 72 per cent agreed that the course was very useful in discharging their formal duties; 98 per cent agreed that the course content was suitable concerning the topics, sequence and official duties; 77.4 per cent approved of the adequacy of duration of the course; 97.8 per cent were satisfied with the teaching and 90 per cent perceived the programme as good and excellent. Even though the findings were mainly very positive, they were limited to the reaction of the 
particular cohort participants for the theoretical phase of the course only and did not involve the preceding 6-month attachment phase in school. Application of the knowledge and skills acquired from this phase in the real job was also not possible to measure as the participants were just mid-way through their course and have not had the opportunity to apply what they learned in the leadership or senior management posts in the school.

More studies ensued and some in the form of doctoral studies. Kamaruzaman (2009) conducted a doctoral study involving questionnaire administered to $271 \mathrm{NPQH} / \mathrm{NPQEL}$ graduates seeking their perceptions on the acquiring of knowledge and skills through this programme. Interviews were also conducted involving three education directors, three lecturers of the programme, eight NPQH graduates, four school principals and four headmasters. The purpose of the study was to evaluate the impact of the NPQH programme based on three main levels- reaction, learning, and behaviour. The study found that respondents were satisfied with the programme as they could acquire knowledge and skills and apply the same at their workplace.

Another doctoral study in the form of an evaluative case study was conducted by Singh (2010). The study sought perceptions of eighteen incumbent secondary school headteachers who were graduates of the NPQH programme to determine the effectiveness of the programme in their headship practices. The study was a qualitative dominant mixed methods research which used the semi-structured interview as its main method and adopted a mixed approach of key elements from various evaluation models. The study found that the respondents agreed that all the 27 units of study in the programme provided them with good preparation for headship. The headteachers also acknowledged the programme has helped them in the journey to headship and the eventual incumbency of the post, particularly in the theoretical knowledge provided by the programme, the increase in the confidence felt by the graduates and the wellplanned structure of the programme.

The respondents were also asked on how the programme could be improved and some recommendations emerged. The respondents suggested that the programme should utilize experiences of NPQH headteachers so that the participants could be given accounts from different school contexts. There was also a strong call for a supportive policy for headship as there was no clear policy in place since the beginning of the programme in 1999. The respondents also called for a better balance of theoretical input and hands-on or practical opportunities in the programme. It was also found from this study that many an NPQH graduate was frustrated as they were not given the headship post after graduating for some time from the programme. This study called for a clear and supportive policy to be put in place for the graduates of this programme and improvements to the programme.

\section{FROM RESEARCH TO PRACTICE: THE NEW MODE NPQEL (2011)}

Research improves the collective understanding of education whereby more information is sought for better understanding and new areas are explored (Creswell, 2015). Echoing this, the studies done on NPQH/NPQEL programme found that the programme was an important tool in preparing the future school leaders and it should 
be continuously improved to fulfil the current demands of educational leadership and school effectiveness. This programme has been the only structured programme of headship preparation in Malaysia.

The studies, however, seem to show that there was a lack of a clear policy towards the career path of the graduates which could eventually lead them to headship post. This was a general feeling of many graduates as they waited for their opportunity to assume management posts in the school. This factor alongside many other recommendations and suggestions to further improve the programme led to an initiative to change the structure of the programme. The effort came about sometime in mid-2010 as the eventual last cohort of the existing one-year NPQEL programme began their course. The initiative to come up with a proposal to change the programme stemmed from the intention to make this programme more meaningful and beneficial in preparing effective future school heads.

In the planning and structuring of the new mode NPQEL programme, it was thought that the shortcomings of the one-year programme were due to certain reasons. Firstly, the one-year programme was considered a long term programme for practising educators and they were given study leave to attend the programme. This study leave puts their position under the Scholarship Division of the Ministry of Education. They were out of their position in their existing school and undertook this programme on a full-time basis. After completing the programme in one year, the graduates could choose to further their studies at the degree or masters level. This was an attraction of the NPQH programme then as the participants had an opportunity to further their study to attain the higher academic qualification. The downside of this practice was the age limit of the participants who eventually went on to further studies. The stipulated age limit for those who went to study for their degree was 45 years old and those vying for Masters had to be less than 43 years old.

This inadvertently attracted younger teachers to do the NPQH/NPQEL programme and it created an age limit for the participants of the NPQH. Participants who came into the programme with Masters qualification did not have any official link to further their study, so they were posted back to schools or other educational institutions such as teacher training colleges or education departments. However, some of the senior teachers or administrators were also wary of taking up the programme as they had to relieve their posts as this was a full-time study programme. Upon their return to school after a year of doing the NPQH, some could find their posts replaced by others. It is a policy that anyone who leaves the school for a period of more than 28 days for further study entitles the school to find a replacement.

This fact coupled with a lack of a clear policy for the appointment of the graduates to headship kept many a senior school administrator away from joining the programme. Having the participants to undertake a 6-month first phase of the NPQH/NPQEL programme gave many a feeling that there is a lack of hands-on or practical experience. The second phase of the 6-month attachment programme provided hands-on experience and an opportunity for the participants to conduct school improvement projects. The attachment phase, however, was undertaken in another school and not the participants' schools. 
All these concerns were thought of carefully when drafting the new mode NPQEL programme. To begin with, the new mode was aimed at senior teachers and administrators who were close to assuming headship due to their considerable tenure. This was not feasible in the existing mode as age was an issue due to the link to further studies. The link to automatic sponsored further studies was taken off in the new mode. This also relieved the programme of age limit issue. There was no specific age limit for participants to join the new mode programme. To check the problem of senior teachers having to relinquish their posts to join the NPQH programme, as was the case of the existing programme, the new mode was structured on a blended learning approach. The senior administrators will now still assume their posts while attending the programme.

The blended learning approach of the new mode combined the face to face approach with e-learning and consultation. Care was taken as not to get the participants out of their workplace for more than 28 days at a time, to avoid the need for replacement teachers and more costs. Therefore, the programme was designed with a face to face phase which lasted a maximum of 25 days. This is only for the first phase whereas the face to face period for the second phase and third phase of the programme is two weeks and one week consecutively. The new mode NPQEL programme was designed to allow participants to come on-site to IAB as well as to do the course at their respective stations through e-learning. The NPQEL programme model is presented in Figure 1.

\section{NPQEL Model}

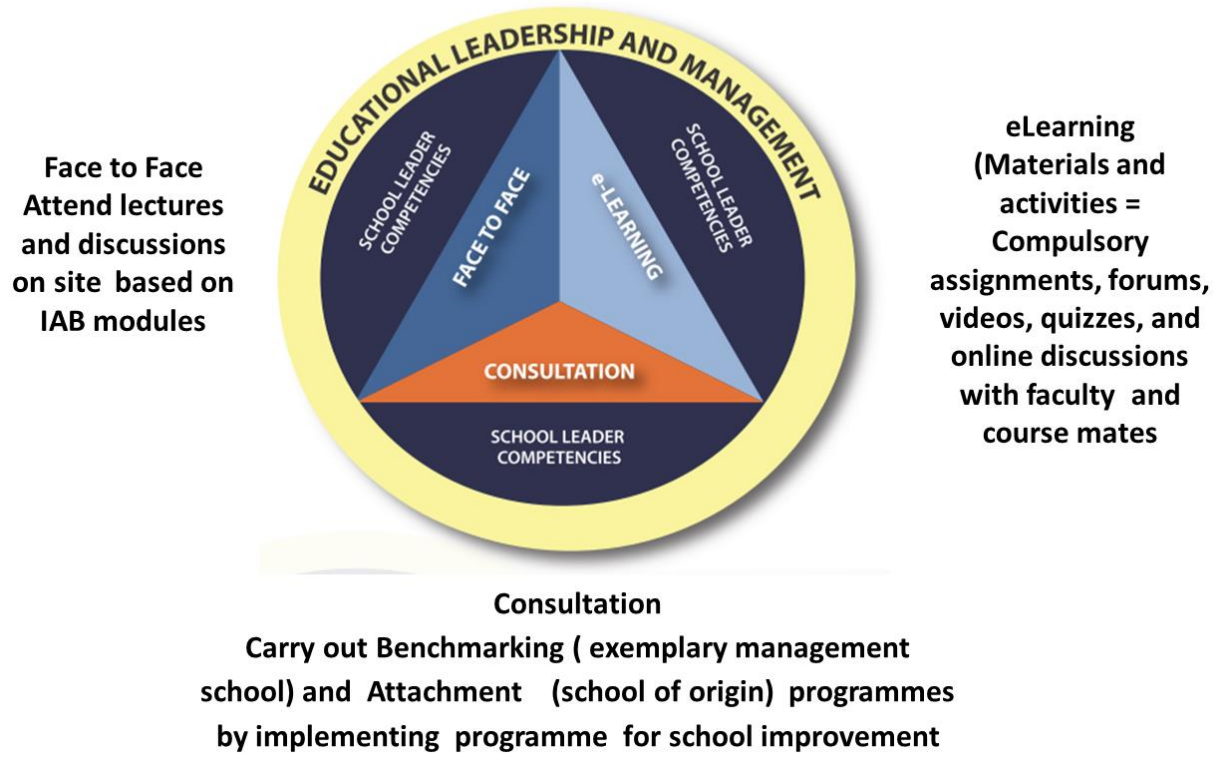

Figure 1. NPQEL Programme Model

The total course duration of the new mode NPQEL is five months (20 weeks). It comprises of six weeks of face to face and 14 weeks of e-learning. During the e-learning, participants also carry out two consultation activities: the Benchmarking programme for two weeks and the Attachment programme for eight weeks. Figure 2 shows the structure of the NPQEL programme. 


\begin{tabular}{|c|c|c|c|c|}
\hline \multicolumn{2}{|c|}{$\begin{array}{l}\text { - Face-to-face } \\
\text { ( } 3 \text { weeks) } \\
\text { Benchmarking Programme } \\
\text { in selected school } \\
\text { ( } 2 \text { weeks) }\end{array}$} & \multicolumn{2}{|c|}{$\begin{array}{c}\text { Face-to-face } \\
\text { (2 weeks) } \\
\text { - Examination of Phase } 1 \\
\text { - Portfolio Submission } \\
\text { - Attachment Programme } \\
\text { in own school } \\
\text { and } \\
\text { e-Learning } \\
\text { (8 weeks) }\end{array}$} & $\begin{array}{c}\text { - Face-to face } \\
\text { (1 week) } \\
\text { - Examination of Phase } 2 \\
\text { - Fitness Test } \\
\text { - Portfolio Submission }\end{array}$ \\
\hline $\begin{array}{c}\text { Face-to-face } \\
\text { Module of Basics } \\
(6 \mathrm{~h}) \\
\text { Module } 1(24 \mathrm{~h}) \\
\text { Module } 2(24 \mathrm{~h}) \\
\text { Module } 4(24 \mathrm{~h}) \\
\text { Action Research }\end{array}$ & $\begin{array}{l}\text { Module of Basics } \\
\quad(12 \mathrm{~h}) \\
\text { Module } 1(12 \mathrm{~h}) \\
\text { Module } 2(12 \mathrm{~h}) \\
\text { Module } 4(12 \mathrm{~h})\end{array}$ & $\begin{array}{l}\text { Face-to-face } \\
\text { Module } 3(18 \mathrm{~h}) \\
\text { Module } 5(18 \mathrm{~h}) \\
\text { Module } 6(18 \mathrm{~h})\end{array}$ & $\begin{array}{l}\text { Module } 3(24 \mathrm{~h}) \\
\text { Module } 5(24 \mathrm{~h}) \\
\text { Module } 6(24 \mathrm{~h})\end{array}$ & $\begin{array}{c}\text { Management of Counseling } \\
\text { Colloquium } \\
\text { Knowledge Sharing of School Leaders }\end{array}$ \\
\hline
\end{tabular}

Figure 2. NPQEL Programme Structure

The new mode NPQEL curriculum was formulated using the domains in School Leaders' Competency Model developed in IAB. The curriculum contains the basic module which is the Educational Leadership and Management overarching the six main domains; policy and direction, instructional and achievement, managing change and innovation, resource and operation, people and relationships, and personal effectiveness (Figure 3).

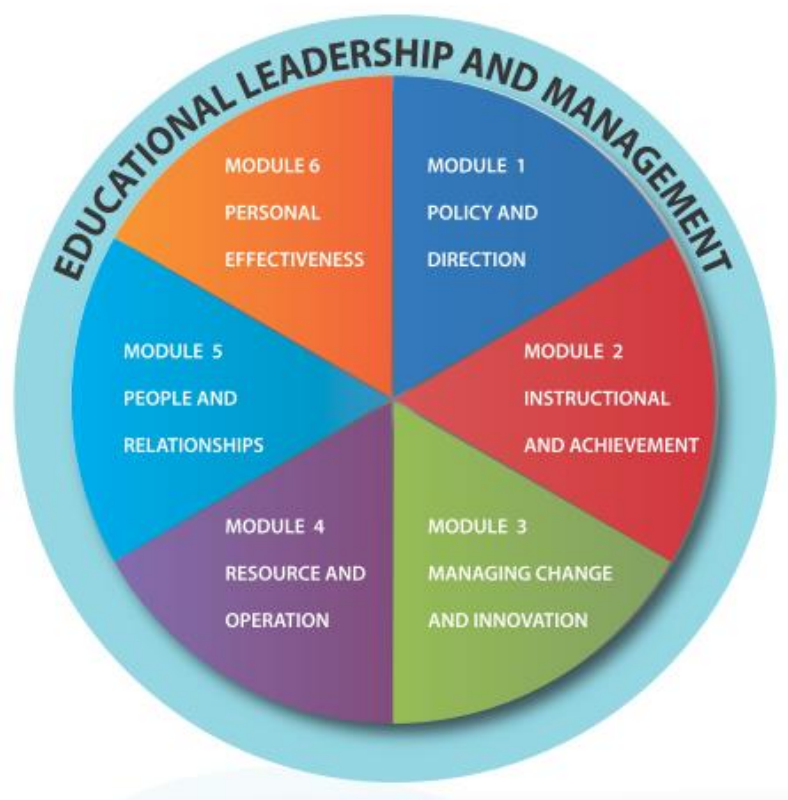

Figure 3. NPQEL Curriculum Model 
The new mode NPQEL which was proposed in late 2010 was approved and its first cohort of 114 participants began the course in July 2011. At the same time efforts were undertaken to make this programme a mandatory prerequisite for the post of headship in Malaysia. In 2012, two groups of participants totalling 246 went through this programme. The number of participants increased by the year as more centres were allocated to conduct the training. A total number of 1005 participants attended this programme in 2013 and the number increased in the following years until 2017. In 2018, there was a smaller number of intake as IAB embarked on a slightly different approach in the delivery of the programme while still retaining the period and the basic structure of the blended training. The following Table 1 shows the number of participants in the NPQH programme since 1999 and the number in the new mode NPQEL since 2011.

Table 1: Yearly Number of NPQH/NPQEL Participants

\begin{tabular}{|c|c|c|c|c|}
\hline Kohort & Year & Secondary School & Primary School & Total \\
\hline NPQH Cohort 1 & 1999 & 216 & 43 & 259 \\
\hline NPQH Cohort 2 & 2000 & 0 & 243 & 243 \\
\hline NPQH Cohort 3 & 2000 & 130 & 0 & 130 \\
\hline NPQH Cohort 4 & 2001 & 67 & 58 & 125 \\
\hline NPQH Cohort 5 & 2001 & 36 & 0 & 36 \\
\hline NPQH Cohort 6 & 2002 & 58 & 26 & 84 \\
\hline NPQH Cohort 7 & 2003 & 50 & 0 & 50 \\
\hline NPQH Cohort 8 & 2004 & 67 & 130 & 197 \\
\hline NPQH Cohort 9 & 2005 & 40 & 132 & 172 \\
\hline NPQH Cohort 10 & 2006 & 96 & 76 & 172 \\
\hline NPQH Cohort 11 & 2007 & 78 & 67 & 145 \\
\hline NPQEL Cohort 1 & 2008 & 83 & 58 & 141 \\
\hline NPQEL Cohort 2 & 2009 & 112 & 22 & 134 \\
\hline NPQEL Cohort 3 & 2010 & 51 & 17 & 68 \\
\hline NPQEL Intake 1 & 2011 & 48 & 66 & $114^{*}$ \\
\hline NPQEL Intake 1 & 2012 & 52 & 73 & $125^{*}$ \\
\hline NPQEL Intake 2 & 2012 & 67 & 54 & $121^{*}$ \\
\hline NPQEL Intake 1 & 2013 & 280 & 217 & $497^{*}$ \\
\hline NPQEL Intake 2 & 2013 & 263 & 247 & $510^{*}$ \\
\hline NPQEL Intake 1 & 2014 & 144 & 259 & $403^{*}$ \\
\hline NPQEL Intake 2 & 2014 & 238 & 379 & $617^{*}$ \\
\hline NPQEL Intake 1 & 2015 & 158 & 379 & $537^{*}$ \\
\hline NPQEL Intake 2 & 2015 & 335 & 510 & $845^{*}$ \\
\hline NPQEL Intake 1 & 2016 & 247 & 612 & $859^{*}$ \\
\hline NPQEL Intake 2 & 2016 & 186 & 635 & $821^{*}$ \\
\hline NPQEL Intake 1 & 2017 & 189 & 175 & $865^{*}$ \\
\hline NPQEL Intake 2 & 2017 & 132 & 585 & $240^{*}$ \\
\hline NPQEL Intake 1 & 2018 & 65 & 105 & $152^{*}$ \\
\hline NPQEL Intake 2 & 2018 & 47 & 9368 \\
\hline TOTAL & & 3537 & & \\
\hline NPW mode & & 574 & \\
\hline
\end{tabular}

* New mode

Source: NPQEL secretariat, IAB (2018). 


\section{RESEARCH ON THE NEW MODE NPQEL}

Research on the NPQEL new mode which was introduced in 2011 is mostly done by the organisers of this programme, Institut Aminuddin Baki. A study on the first intake of 2011 batch was conducted and reported in 2012 (IAB, 2012a). The study was done to investigate the effectiveness of this programme. A questionnaire of 110 items was administered to 63 participants who completed the programme. The finding of the study showed that the content of the programme and assessment after the programme were scored the highest. Also scored high were the learning material, e-learning activities, delivery of lecturers, and the benchmark as well as attachment programmes. The only area which was scored at a moderate level was the access to the internet at the course site.

A similar study was conducted by IAB on the first intake of 2012 batch using the 110 items questionnaire (IAB, 2012b). The finding of this quantitative study which involved 113 participants showed a similar response where the participants were very satisfied with the materials, content, benchmark and attachment programmes, as well as elearning activities and assessment. Again, access to the internet was the concern raised by the participants. A similar reaction was received from participants in a study using the same instrument for the second intake of 2013 batch (IAB, 2014a) and second intake of batch 2014 (IAB, 2015a) whereby all the aspects received a satisfactory score except for the internet access which was scored at a moderate level.

Another study that involved the first intake of the year 2012 participants was a pre and post-test to ascertain whether there was a significant difference in the knowledge, understanding as well as competencies of the participants before joining the 5-month NPQEL programme and after they complete the programme (IAB, 2012c). This quantitative study responded by 125 participants found that the participants reported improvement in all three aspects for all modules taught and this pointed to the benefit of this programme to the participants. A similar study was conducted on the second intake of the year 2012 involving 121 participants (IAB, 2013a). Similar reactions were given by participants who reported an improvement in the aspect of knowledge, understanding as well as competencies in all the taught modules.

A similar pre and post-test study were conducted on the first intake of the year 2013 with a sample of 497 participants (IAB, 2013b). The finding of this study also showed similar results as the studies conducted in the year 2012 batch. Improvement in the aspect of knowledge, understanding and competencies in all the modules taught was reported by the participants. Again this study showed that the NPQEL programme is beneficial in bringing about positive changes to the participants.

A qualitative study on the impact of the NPQEL programme on the incumbent middle managers was conducted in 2014, involving 18 NPQEL graduates assuming middle management roles, 19 superordinates of these graduates and 18 subordinates (IAB, 2014b). The findings of the study found that the impact of the programme could be categorised under two aspects - the impact on practices and impact on selfdevelopment. The study pointed to the relevance of the content of NPQEL to these respondents and the readiness to assume the top leadership post in the school. 
A relatively larger mixed-methods study on the impact of the NPQEL programme was conducted in 2015, using a random stratified sample of 720 school leaders - 217 principals of secondary schools and 503 headteachers of primary schools from the whole country for the quantitative part. This was followed with 48 respondents, chosen through purposive sampling, for the qualitative part involving District Education Officers, Senior Assistants and Parent-Teacher Association officials (IAB, 2015b). The interviews were done with the 48 respondents were treated as triangulation data for the quantitative data derived from the questionnaires. The finding of this study pointed towards high-level practices in leadership, self-development and organisation development by these top school leaders. High scores were also obtained for their human relationship as well as change and innovation practices.

The studies conducted on the new mode NPQEL pointed to the high value of the programme to the practices and self-development of school leaders. The findings of these studies also led to the Ministry of Education's directive that beginning 1 July 2014 all new appointments of school heads must be from those who have completed the NPQEL course. This mandatory requirement was in alignment to the aspiration expressed in the fifth shift of the Malaysian Education Blueprint (2013 -2025); to ensure that there are high-performing leaders in every school. This gave the Malaysian school leadership a new perspective whereby newly appointed heads would have been trained before they assumed the post, an aspiration of IAB since the programme was introduced in 1999.

\section{THE NPQEL VERSION 2018 - A NEW ERA}

The NPQEL programme went through another change in the year 2018 and a new version of NPQEL is introduced. The NPQEL version 2018, also known as the NPQEL 2.0, was formulated to create visionary leaders, leaders of learning and change leaders that are envisaged to impact upon the school excellence through self-professional enhancement and self qualities of the leaders (IAB, 2018). A few changes are made to the structure of the new version NPQEL to enable more participants to be trained. In 2017 , it was found that the ratio of reserve candidates for headship to the availability of new posts was 1:1. This led to almost all the candidates who obtained the NPQEL qualification, regardless of whether they achieved the score of less than CGPA 3.75, were considered and given the post. The new version NPQEL was planned to enable a ration of 1:3 which means for every post available, there are three candidates to be considered. Only the best candidates would be considered and this will ensure the highest standards amongst the newly appointed heads.

One significant change in the structure is the shortening of the training period, from five months in the new mode NPQEL 2011 to three months and three weeks in the NPQEL 2.0. This will lead to three intakes a year totalling 2610 participants compared to the previous two intakes per year totalling 1740 participants (IAB, 2018). The previous version which was knowledge-based is now replaced by the competency-based approach encompassing ten competencies clustered in four domains. The first domain is Visionary and it contains one competency - Strategic Thinking. The second domain, Managing Change comprises of three competencies, namely, Leading Change, Decision Making and Problem Solving. The third domain is Creating Excellent Organisation and 
the three competencies within this domain are Leading Learning, Capacity Building and Building Relationship and Network. The fourth domain, Competent, subsumes three competencies, i.e. Effective Communication, Leadership and Towering Personality (Figure 4).

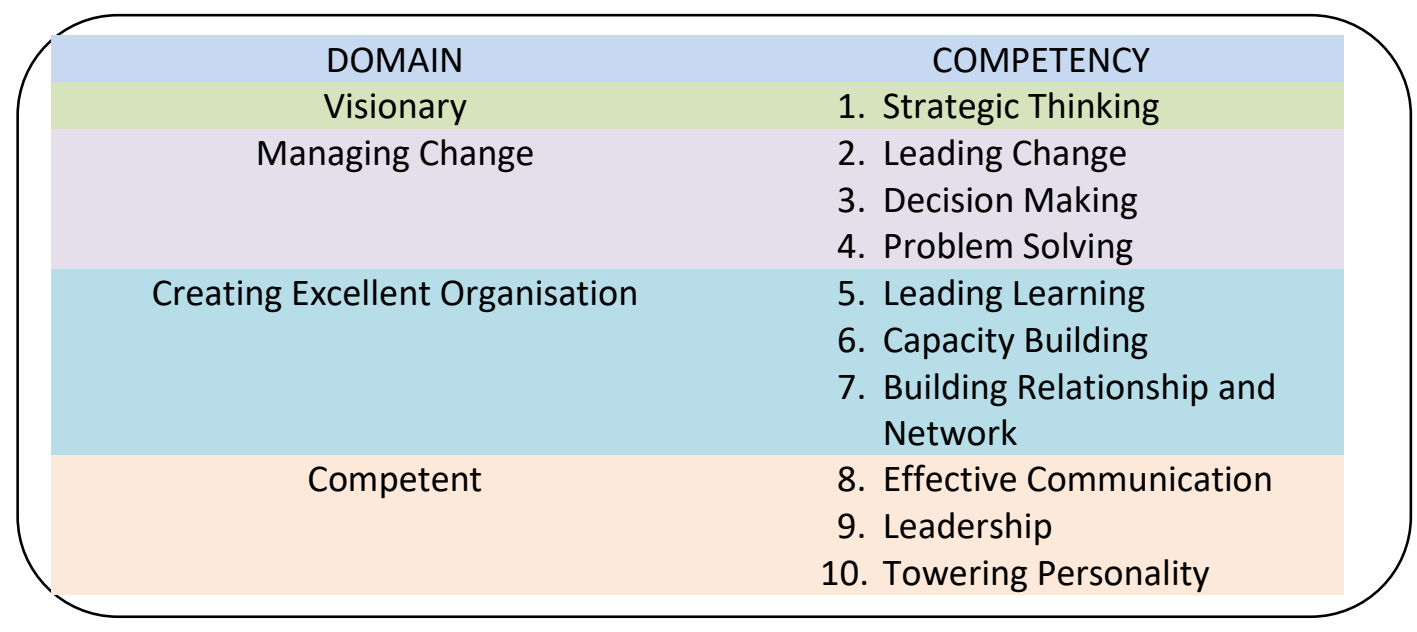

Source: IAB (2018).

Figure 4. Competency Domains of NPQEL Version 2018

The participants are also expected to carry out two apprenticeships. The first is for five days and the participants are to learn hands-on about leadership and management in a school. The second apprenticeship is for the participants to do job shadowing in a school within the same district for a period of six weeks whereby the participants are required to be in the school for at least three days a week totalling at least 18 days within the six months.

There have been two intakes each for the new version NPQEL in the year 2018 and 2019 respectively. There has not been any reported or published study done thus far to see the effectiveness of this new version.

\section{CONCLUSION}

The NPQEL programme with its new blended learning mode seems to be the answer for the future of school leadership in Malaysia. The NPQEL certified aspiring heads are now beginning to fill in the posts left vacant by retiring headteachers. On average, about 10 per cent of the 10,000 schools heads leave the system each year on mandatory retirement at 60 years or some even earlier. The intake of NPQEL participants has been increased from the normal intake of about 1000 per year to about 1500 per year beginning in 2015. The NPQEL version 2018 plans to take up to 2600 participants per year. This is to ensure there is enough pool to choose from to fill in the vacancies from time to time. It is the hope of the Ministry of Education and its aspiration through the Malaysian Education Blueprint 2013-2025 that all schools in Malaysia be administered and led by effective leaders to ensure the quality of schools and the future generation of progressive Malaysians. 


\section{REFERENCES}

Adams, D. (2018). Mastering theories of educational leadership and management. Kuala Lumpur: University of Malaya Press.

Adams, D., Raman Kutty, G. \& Mohd Zabidi, Z. (2017). Educational leadership for the $21^{\text {st }}$ century. International Online Journal of Educational Leadership, 1(1), 1-4.

Adams, D., A. Samat, S. N., A. Samah, H. (2018). Teacher leadership: Going beyond classroom. International Online Journal of Educational Leadership, 2(1), 1-3.

Aziz, M. N. (2003). An investigation into the headship training programme for aspiring primary school headteachers. (Unpublished doctoral thesis), University of Bristol, United Kingdom.

Bajunid, I. A. (1996). Preliminary explorations of indigenous perspectives of educational management: The evolving Malaysian experience. Journal of Educational Administration, 34(5), 50-73.

Brundrett, M. (2001). The development of school leadership preparation programmes in England and the USA: A comparative analysis. Educational Management \& Administration, 29(2), 229-245.

Bush, T. (2008). Leadership and management development in education. London: Sage Publications Ltd.

Bush, T. (1998) The national professional qualification for headship: The key to effective school leadership? School Leadership and Management, 18(3), 321-333.

Bush, T. (2016). Preparation for school principals: Rationale and practice. Educational Management Administration \& Leadership, 44(4), 537-539.

Bush, T., Bell. L. \& Middlewood, D. (2010). Introduction: New directions in educational leadership. In T. Bush, L. Bell \& D. Middlewood (Eds.), The principles of educational leadership \& management (2nd ed., pp. 3-12). London, UK: Sage Publications Ltd.

Bush, T. \& Glover, D. (2003). School leadership: Concepts and evidence. Nottingham: National College for School Leadership.

Bush, T. \& Jackson, D. (2002). A preparation for school leadership: International perspectives. Education Management and Administration, 30(4), 417-429.

Cabinet Committee (1979). Report on the Implementation of Educational Policy. Kuala Lumpur: Dewan Bahasa dan Pustaka

Cheng, K. -M. (1995). The neglected dimension: Cultural comparison in educational administration. In K. -C. Wong and K. -M. Cheng (Eds.), Educational Leadership and Change: An international perspective (pp. 87-102). Hong Kong: Hong Kong University Press.

Council of Chief State School Officers (CCSSO). (1996). Interstate school leaders licensure consortium (ISLLC) standards for school leaders. Washington, DC.

Creswell, J. W. (2015). Educational research: planning, conducting and evaluating quantitative and qualitative research (5th ed.). Harlow, Essex: Pearson.

Daniëls, E., Hondeghem, A., \& Dochy, F. (2019). A review on leadership and leadership development in educational settings. Educational Research Review, 27, 110125.

DfEE. (1998). Teachers: Meeting the Challenge of Change. Green Paper. London: HMSO.

EPRD. (2006). Laporan kajian penilaian graduan NPQH. [Report on the assessment study of NPQH graduates]. Putrajaya: Educational Planning and Reseach Division. 
Guskey, T. R. (2000). Evaluating professional development. Thousand Oaks, CA: Corwin Press, Inc.

Hallinger, P., Adams, D., Harris, A. \& Jones, S. M. (2018). Review of conceptual models and methodologies in research on principal instructional leadership in Malaysia: a case of knowledge construction in a developing society. Journal of Educational Administration, 56(1), 104-126.

Hallinger, P. \& Heck, R. (1999). Can leadership enhance school effectiveness? In T. Bush, L. Bell, R. Bolam, R. Glatter \& P. Ribbins (Eds.), Educational management: Redefining theory, policy and practice (pp. 178-190). London: Paul Chapman Publishing Ltd.

Hallinger, P. \& Kantamara, P. (2000). Educational change in Thailand: Opening a window onto leadership as cultural process. School Leadership and Management, 20(2), 189-205.

Hallinger, P. \& Snidvongs, K. (2008). Educating leaders: Is there anything to learn from business management? Educational Management Administration \& Leadership, 36(1), 9-31.

Huber, S. G. \& West, M. (2002). Developing school leaders: A critical review of current practices, approaches, and issues and some directions for the future. In K. Leithwood and P. Hallinger (Eds.), Second international handbook of educational leadership and administration (pp 1071-1102). Dordrecht, Netherlands: Kluwer Academic Publishers.

Institut Aminuddin Baki (IAB). (2012a). Kajian keberkesanan program NPQEL ambilan 1 tahun 2011. [A study on the effectiveness of NPQEL intake 1 year 2011]. Genting Highlands: Institut Aminuddin Baki.

Institut Aminuddin Baki (IAB). (2012b). Kajian keberkesanan program NPQEL ambilan 1 tahun 2012. [A study on the effectiveness of NPQEL intake 1 year 2012]. Genting Highlands: Institut Aminuddin Baki.

Institut Aminuddin Baki (IAB). (2012c). Ujian pra dan ujian pasca aspek pengetahuan dan kefahaman serta kemahiran program NPQEL bagi ambilan 1 tahun 2012. [Pre and post-test study on knowledge, understanding and competencies of NPQEL programme intake 1 year 2012]. Genting Highlands: Institut Aminuddin Baki.

Institut Aminuddin Baki (IAB). (2013a). Ujian pra dan ujian pasca aspek pengetahuan dan kefahaman serta kemahiran program NPQEL bagi ambilan 2 tahun 2012. [Pre and post-test study on knowledge, understanding and competencies of NPQEL programme intake 2 year 2012]. Genting Highlands: Institut Aminuddin Baki.

Institut Aminuddin Baki (IAB). (2013b). Ujian pra dan ujian pasca aspek pengetahuan dan kefahaman serta kemahiran program NPQEL bagi ambilan 1 tahun 2013. [Pre and post-test study on knowledge, understanding and competencies of NPQEL programme intake 1 year 2013]. Genting Highlands: Institut Aminuddin Baki.

Institut Aminuddin Baki (IAB). (2014a). Kajian keberkesanan program NPQEL ambilan 2 tahun 2013. [A study on the effectiveness of NPQEL intake 2 year 2013]. Genting Highlands: Institut Aminuddin Baki.

Institut Aminuddin Baki (IAB). (2014b). Amalan pengurusan dan kepimpinan pemimpin pelapis lulusan NPQEL mod baharu: Satu kajian impak. [Management and 
leadership practices of NPQEL new mode trained next generation leaders: An impact study]. Bandar Enstek: Institut Aminuddin Baki.

Institut Aminuddin Baki (IAB). (2015a). Kajian keberkesanan program NPQEL ambilan 2 tahun 2014. [A study on the effectiveness of NPQEL intake 2 year 2014]. Bandar Enstek: Institut Aminuddin Baki.

Institut Aminuddin Baki (IAB). (2015b). Impak NPQEL terhadap kepemimpinan, pembangunan diri dan organisasi. [The impact of NPQEL on leadership, selfdevelopment and organisational development]. Bandar Enstek: Institut Aminuddin Baki.

Institut Aminuddin Baki (IAB). (2018). Panduan Pelaksanaan Program Kelayakan Profesional Pemimpin Pendidikan Kebangsaan NPQEL Versi 2018. [Guideline for the implementation of National Professional Qualification for Educational Leaders version 2018]. Bandar Enstek: Institut Aminuddin Baki.

Kamaruzaman, M. (2009). Keberkesanan program kelayakan profesional kepengetuaan kebangsaan (NPQEL). [The effectiveness of the National Professional Qualification for Educational Leaders (NPQEL) programme] (Unpublished doctoral thesis), Universiti Kebangsaan Malaysia, Malaysia.

Leithwood, K., Day, C., Sammons, P., Harris, A. \& Hopkins, D. (2006). Seven strong claims about successful school leadership. London: Department for Education and Skills.

Lodge, C. (1998). Training aspiring heads on NPQH: Issues and progress. School Leadership \& Management, 18(3), 347- 357.

Lumby, J. (2014). Leadership preparation: Engine of transformation or social reproduction? Journal of Educational Administration and History, 46(3), 306325. doi:10.1080/00220620.2014.919901.

Lumby, J., Crow, G. \& Pashiardis, P. (2008). International handbook on the preparation and development of school leaders. New York, NY: Routledge.

Ministry of Education. (2012). Malaysia Education Blueprint 2013-2025 (Preschool to Post-Secondary Education). Putrajaya, Malaysia: Ministry of Education Malaysia.

Murphy, J. (1997). Putting New School Leaders to the Test. Education Week. (19 November 1997).

Pashiardis, P., \& Johansson, O. (2016). Successful school leadership : International perspectives. London: Bloomsbury Publishing Plc.

Reynolds, D. \& Teddlie, C. (2000). The Process of School Effectiveness. In C. Teddie and D. Reynolds. (Eds.), The International Handbook of School Effectiveness Research. London: Falmer Press.

Hassan, R., Abdul Halim, R., \& Syed Imam, S. S. J. (2006). Evaluation of Institut Aminuddin Baki training programme: A study on the NPQH cohort 9/2005. Paper presented at the 13th National Educational Management and Leadership Seminar. Institut Aminuddin Baki, Genting Highlands.

Sammons, P. (1999). School Effectiveness: Coming of Age in the Twenty-First Century. Lisse, Netherlands: Swets and Zeitlinger.

Sammons, P., Hillman, J. \& Mortimore, P. (1995). Key Characteristics of Effective Schools: A Review of School Effectiveness. London: Institute of Education.

Shah, S. (2006). Educational leadership: an Islamic perspective. British Educational Research Journal, 32(3), 363-385. 
Singh, G. S. B. (2010). The National Professional Qualifications for Headship (NPQH) programme for secondary school headteachers in Malaysia: An evaluative case study. (Unpublished Doctoral thesis, University of Birmingham, UK). Retrieved from http://etheses.bham.as.uk/588/1/BishenSingh10EdD.pdf

Walker, A. (2015). Clones, drones and dragons: Ongoing uncertainties around school leader development. School Leadership and Management, 35(3), 300-320. doi:10.1080/13632434.2015.1041488.

Wan Zahid. (1995). Dasar Pendidikan Kebangsaan: Ke arah pemantapan dan pelaksanaan Dasar Pendidikan Negara selaras dengan tuntutan Wawasan 2020. The National Education Policy: Towards intensification and implementation of the National Education Policy in accordance to the Vision 2020. In Siti Fatimah and Anuar Ahmad (Eds.), Proceedings of the National Seminar: The nation's education in the 21st century. Bangi: Universiti Kebangsaan Malaysia.

Willower, D. J. and Forsyth, P. (1999). A brief history of scholarship on educational administration. In J. Murphy and K. S. Louis (Eds.), The handbook of research on educational administration (2nd ed., pp. 1-23). San Francisco, CA: Jossey-Bass.

Zelvys, R., Dukynaite, R., Vaitekaitis, J., \& Jakaitiene, A. (2019). School leadership and educational effectiveness: Lithuanian Case in Comparative Perspective. Management: Journal of Contemporary Management Issues, 24, 17-36. 